\title{
Combined oceanic and atmospheric influences on net accumulation on Devon Ice Cap, Nunavut, Canada
}

\author{
William COLGAN, ${ }^{1,2}$ Martin SHARP ${ }^{1}$ \\ ${ }^{1}$ Arctic and Alpine Research Group, Department of Earth and Atmospheric Sciences, University of Alberta, Edmonton, \\ Alberta T6G 2E3, Canada \\ ${ }^{2}$ Cooperative Institute for Research in Environmental Sciences, University of Colorado, Boulder, Colorado 80309-0216, USA \\ E-mail: liam.colgan@colorado.edu
}

\begin{abstract}
An annual net accumulation history of the high-elevation region of Devon Ice Cap, Nunavut, Canada, was reconstructed for the period 1963-2003 using five shallow firn cores. Annual net accumulation decreased significantly after 1989. To explain variability in the reconstructed annual net accumulation record, monthly and seasonal moisture-source probabilities were calculated for gridcells throughout the Arctic during 1979-2003. Seasonally, moisture-source probabilities reach a maximum in northern Baffin Bay in late summer/early fall and approach zero throughout the Arctic in winter. Latesummer/early-fall moisture-source probabilities were significantly higher around the North Open Water (NOW) Polynya during the 4 year period of highest annual net accumulation during the 1979-2003 period (1984-87), than during the 4 year period with the lowest annual net accumulation (1994-97). This is due to both a significant decrease in the sea-ice fraction and a significant increase in lowelevation atmospheric transport over the NOW area during the high net accumulation period. Anomalously low net accumulation and anomalously high firnification rates during the 1989-2003 period suggest that a change in ice dynamics, rather than a change in surface mass balance, may explain recent ice-cap thickening observed by laser altimetry.
\end{abstract}

\section{NOTATION}

$\sigma[c]$ Total uncertainty in annual net accumulation $\left(\mathrm{m}\right.$ w.e. $\mathrm{a}^{-1}$ )

$\sigma\left[c_{\mathrm{C}}\right] \quad$ Uncertainty in annual net accumulation due to $\mathrm{m}$ to m w.e. conversion (\%)

$\sigma\left[c_{l}\right]$ Uncertainty in annual net accumulation due to peak location (\%)

$\sigma\left[c_{\mathrm{p}}\right]$ Uncertainty in net accumulation due to meltwater percolation between layers (\%)

A Area $\left(\mathrm{km}^{-2}\right)$

b Back-trajectory points below $500 \mathrm{~m}$ elevation (hours)

$c \quad$ Mean annual net accumulation rate $\left(\mathrm{m}\right.$ w.e. $\mathrm{a}^{-1}$ )

d Number of days

$D \quad$ Site-specific low-elevation atmospheric transport density $\left(\mathrm{km}^{-2}\right)$

$D^{\prime} \quad$ Theoretical maximum site-specific low-elevation atmospheric transport density $\left(\mathrm{km}^{-2}\right)$

m Given month

$M \quad$ Moisture-source index value $\left(\mathrm{km}^{-2}\right)$

$M^{\prime} \quad$ Theoretical maximum moisture-source index value $\left(\mathrm{km}^{-2}\right)$

O Open-water fraction (dimensionless)

$O^{\prime} \quad$ Theoretical maximum open-water fraction (dimensionless)

$P \quad$ Relative moisture-source probability (dimensionless)

$s \quad$ Given season

$S \quad$ Sea-ice fraction (dimensionless)

$w \quad$ Number of points in a running mean

x Given G814 cell

y Given G4640 cell

\section{INTRODUCTION}

There is a significant discrepancy between the observed rate of sea-level rise $\left(1.5 \pm 0.5 \mathrm{~mm} \mathrm{a}^{-1}\right)$ and the rate calculated from the sum of the best estimates of freshwater inputs to the ocean and thermal expansion of sea water $(0.7 \pm$ $1.5 \mathrm{~mm} \mathrm{a}^{-1}$; Cazenave and Nerem, 2004). This discrepancy indicates that inaccuracies are likely to exist in sea-level observations or calculations of the major contributions to sea-level rise, or both. This provides a motivation to improve the quantification of glacier and ice-cap contributions to sea-level change (Cazenave and Nerem, 2004). Outside of Greenland and Antarctica, the Canadian Arctic Archipelago contains the largest area of glaciated terrain in the world (Dyurgerov and Meier, 2005). Although the potential contribution of the Canadian Arctic ice caps to sea-level rise is far less than that of the ice sheets in Greenland and Antarctica, their smaller size and more temperate environs make them potentially significant short-term contributors to eustatic sea-level rise (Dowdeswell, 1995; Abdalati and others, 2004). The $14010 \mathrm{~km}^{2}$ Devon Ice Cap $\left(75^{\circ} \mathrm{N}, 82^{\circ} \mathrm{W}\right.$; Fig. 1) is $880 \mathrm{~m}$ thick at its deepest point, and has an estimated volume of $3980 \mathrm{~km}^{3}$, equivalent to $\sim 10 \mathrm{~mm}$ sealevel rise if melted completely (Dowdeswell and others, 2004). It is believed to be in long-term negative mass balance (Koerner, 2005), losing an estimated $1.6 \pm 0.7 \mathrm{~km}^{3}$ of water equivalent (w.e.) per year since 1960 (Burgess and Sharp, 2004).

Although only $19 \%$ of the area of Devon Ice Cap lies above $1200 \mathrm{~m}$ (Dowdeswell and others, 2004), the highelevation region is of interest because its mass-balance variations are poorly correlated with the overall net balance of the northwest sector of the ice cap, which has been measured annually since 1961 (personal communication from R. Koerner, 2005; Fig. 2). In the northwest sector as a whole, the annual and summer net balances are well 




Fig. 1. Shaded contour map of Devon Ice Cap (100 m interval), with the high-elevation region enclosed by the $1200 \mathrm{~m}$ contour (black). The locations of the five shallow firn-core sites (A-E) and the northwest sector mass-balance transect (white; Koerner, 1970) are shown. Inset: Devon Ice Cap in the Canadian Arctic Archipelago.

correlated, which suggests that interannual net mass-balance variability is controlled largely by summer melt processes at lower elevations (<1200 m; Koerner, 2002; Abdalati and others, 2004). At higher elevations, even the summer balance may be positive, and variability in snow accumulation may account for much of the variability in annual net balance. Airborne laser altimetry surveys in 1995 and 2000 suggested that the high-elevation region $(>1200 \mathrm{~m})$ of the ice cap was thickening at a rate of up to $20 \mathrm{~cm} \mathrm{a}^{-1}$, and the low-elevation region $(<1200 \mathrm{~m})$ was thinning at a rate of up to $40 \mathrm{~cm} \mathrm{a}^{-1}$ (Abdalati and others, 2004). Although it has been suggested that the recent high-elevation thickening may be due to anomalous accumulation during the 1995-2000 period (Abdalati and others, 2004), a decrease in the rate of firn densification or a long-term reduction in ice outflow from the accumulation zone could also explain the laser altimetry observations.

In order to best predict how the mass balance of Devon Ice Cap will respond to future climatic conditions, presentday climatic controls on mass balance must be well understood. This study aims to create an annually resolved record of the recent (1963-2003) net accumulation history of the high-elevation region of the ice cap from measurements on shallow firn cores. This record is used to (i) investigate the

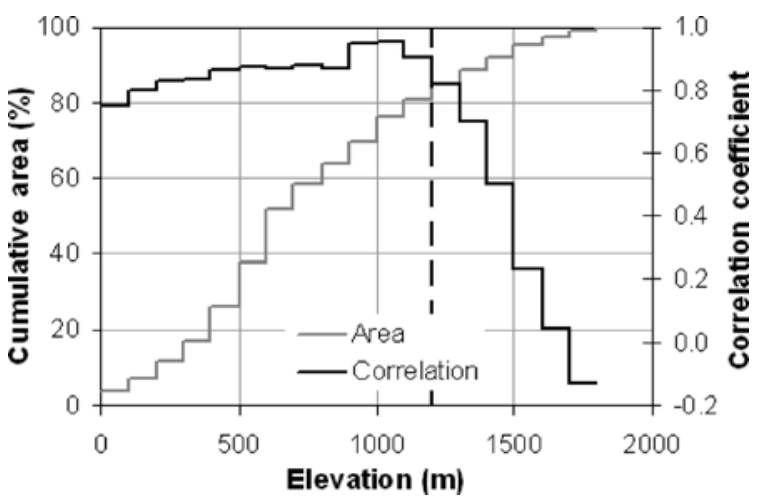

Fig. 2. Correlation between the overall northwest transect annual mass balance and the net balance of individual elevation bands over the period 1961-98 (personal communication from R. Koerner, 2005). The cumulative area of the ice cap with elevation is also shown (Dowdeswell and others, 2004). The dashed curve denotes $1200 \mathrm{~m}$ elevation.

influences of changing atmospheric transport and regional sea-ice cover variability on the annual net accumulation at high elevations and (ii) assess whether the thickening observed by laser altimetry can be explained by anomalous net accumulation or firnification rates.

\section{METHODS}

\subsection{Shallow firn-core recovery}

To reconstruct a net accumulation record for the highelevation region of Devon Ice Cap, five shallow ( $20 \mathrm{~m})$ firn cores (cores A-E) were recovered in April 2004 and April 2005 (Fig. 1; Table 1). The cores were recovered using a Kovacs Mk II corer with a $90 \mathrm{~mm}$ internal barrel diameter. The average measured core diameter was $88 \mathrm{~mm}$. The length and mass of each $\sim 30 \mathrm{~cm}$ firn core section were recorded in the field in order to construct a density profile for each core. The core sections were then wrapped in polyethylene and shipped frozen to the University of Alberta for further analysis.

To constrain the dating of the cores, in situ ${ }^{137} \mathrm{Cs}$ gamma spectrometry was performed in each borehole using an $\mathrm{Nal}(\mathrm{Tl})$ detector connected to a multi-channel analyzer (Dunphy and Dibb, 1994) to identify the depth of the 1963

Table 1. Characteristics of the five shallow firn cores recovered from Devon Ice Cap: recovery year, location and elevation, drill depth, mean number of glaciochemical samples per year, mean net accumulation $(c ; \pm$ standard deviation), uncertainty in annual net accumulation $(\sigma[c])$, mean annual ice fraction ( \pm standard deviation) and the mean number of melt days for the 2000-04 period (Wang and others, 2005)

\begin{tabular}{|c|c|c|c|c|c|}
\hline & Core A & Core B & Core C & Core D & Core $\mathrm{E}$ \\
\hline Recovery year & 2005 & 2005 & 2004 & 2005 & 2005 \\
\hline Latitude $\left({ }^{\circ} \mathrm{N}\right)$ & 75.3448 & 75.3427 & 75.3399 & 75.2390 & 75.4494 \\
\hline Longitude $\left({ }^{\circ} \mathrm{W}\right)$ & 83.7015 & 83.3525 & 82.6763 & 82.0310 & 82.5305 \\
\hline Elevation (m) & 1415 & 1630 & 1825 & 1525 & 1525 \\
\hline Drill depth (m) & 20.5 & 18.5 & 21.0 & 20.6 & 20.7 \\
\hline$c\left(\mathrm{~m}\right.$ w.e. $\left.\mathrm{a}^{-1}\right)$ & $0.22 \pm 0.09$ & $0.22 \pm 0.07$ & $0.25 \pm 0.06$ & $0.17 \pm 0.06$ & $0.23 \pm 0.07$ \\
\hline$\sigma[c]\left(\mathrm{m}\right.$ w.e. $\left.\mathrm{a}^{-1}\right)$ & \pm 0.08 & \pm 0.06 & \pm 0.07 & \pm 0.06 & \pm 0.07 \\
\hline Ice fraction & $0.62 \pm 0.34$ & $0.26 \pm 0.24$ & $0.16 \pm 0.17$ & $0.49 \pm 0.36$ & $0.46 \pm 0.28$ \\
\hline Melt days & 31 & 24 & 18 & 27 & 29 \\
\hline
\end{tabular}


'bomb' layer resulting from fallout from atmospheric thermonuclear weapons testing. Gamma emissions were counted for $20 \mathrm{~min}$ periods at $20 \mathrm{~cm}$ intervals in three discrete energy windows: a background window (885$1001 \mathrm{keV})$, the ${ }^{137} \mathrm{Cs}$ window $(626-749 \mathrm{keV})$ and a ${ }^{109} \mathrm{Cd}$ control window (49-117 keV). The background band registers gamma emissions over a randomly selected energy band. These background emissions are expected to remain constant at depths below the level to which cosmic radiation penetrates. In addition to showing the near-surface increase due to cosmic radiation, the ${ }^{137} \mathrm{Cs}$ band also demonstrates a clear secondary peak at depth that is taken to be the 1963 ${ }^{137} \mathrm{Cs}$ peak (Dunphy and Dibb, 1994). The observed ${ }^{109} \mathrm{Cd}$ activity originated from a ${ }^{109} \mathrm{Cd}$ source fixed to the detector and was monitored to ensure the absence of drift in peak locations. As counts were performed in each of the three bands at $20 \mathrm{~cm}$ intervals from the bottom of the borehole upwards, the $1963{ }^{137} \mathrm{Cs}$ peak is resolved to within $\pm 10 \mathrm{~cm}$.

\subsection{Reconstructing annual net accumulation}

The five firn cores were dated by counting annual layers defined by high-resolution physical and chemical stratigraphy. A detailed description of the physical stratigraphy of each core was made before the cores were sectioned with a bandsaw into slices of $3.1 \pm 0.8 \mathrm{~cm}$ for anion and $\delta^{18} \mathrm{O}$ analyses (Table 1). Individual slices were melted at room temperature in Whirlpak bags and decanted and stored in $20 \mathrm{~mL}$ vials prior to analysis. A Dionex ICS-2500 ion chromatograph was used to measure the concentrations of methanesulphonic acid (MSA: $\left.\mathrm{CH}_{3} \mathrm{SO}_{3} \mathrm{H}\right)$, sulphate $\left(\mathrm{SO}_{4}{ }^{2-}\right)$, nitrate $\left(\mathrm{NO}_{3}{ }^{-}\right)$and chloride $\left(\mathrm{Cl}^{-}\right)$in each sample. The limits of detection (LOD), defined here as three times the standard deviation of the lowest concentration standard in a randomly selected sequence of eight consecutive runs, were $0.086 \mu \mathrm{Eq} \mathrm{L}^{-1}$ for $\mathrm{SO}_{4}{ }^{2-}, 0.109 \mu \mathrm{Eq} \mathrm{L}^{-1}$ for $\mathrm{NO}_{3}{ }^{-}$, $0.079 \mu \mathrm{Eq} \mathrm{L}^{-1}$ for MSA and $0.097 \mu \mathrm{EqL}^{-1}$ for $\mathrm{Cl}^{-}$. The $\delta^{18} \mathrm{O}$ ratios in samples from the highest-elevation core (core $\mathrm{C}$ ) were measured with a GV Isoprime continuous-flow mass spectrometer with EuroEA combustion chamber using an injection volume of $0.1 \mu \mathrm{L}$. The instrument was calibrated with SMOW1675, GISP1381 and SLAP1499, with $\mathrm{CO}_{2}$ as a reference gas.

Annual layers in each core were identified by counting annual $\mathrm{SO}_{4}{ }^{2-}, \mathrm{Cl}^{-}, \mathrm{MSA}$ and $\delta^{18} \mathrm{O}$ (when available) peaks. The net accumulation of a given year is defined as the accumulation between a given pair of $\mathrm{SO}_{4}{ }^{2-}$ peaks. Snowfall $\mathrm{SO}_{4}{ }^{2-}$ concentrations in the Canadian High Arctic peak in February/March (Toom-Sauntry and Barrie, 2002), so the net accumulation in a given year represents the net accumulation from February/March of that year to February/March of the following year. The July/August MSA and $\delta^{18} \mathrm{O}$ (when available) maxima and the January/February $\delta^{18} \mathrm{O}$ (when available) minimum and $\mathrm{Cl}^{-}$maximum (Toom-Sauntry and Barrie, 2002) are identifiable in most annual layers (Fig. 3). In addition, common horizons defined by, for example, unusually high $\mathrm{Cl}^{-}$concentrations were used for core correlation when present in all five records (Fig. 3). The net accumulation (in mw.e.) was derived for the annual layers in each core using the density profiles measured in the field. This created a record of annual net accumulation between 1963 and 2003 for each core site. As the ice content of the core was assessed during logging of the physical stratigraphy (Fig. 3), the ice fraction of each annual layer could be calculated. The annual ice fraction is defined as the fraction of the w.e. net accumulation present as ice, rather than firn, in each annual layer (Table 1). The thinning of annual layers with depth, due to ice deformation, is often a concern when using ice cores to reconstruct annual net accumulation records. In a previous study, however, Pohjola and others (2002) considered the top $18.5 \mathrm{~m}$ of an ice core to be minimally influenced by deformation. We likewise assume negligible flow-induced layer thinning in our annual net accumulation record.

\subsection{Uncertainty in reconstructed net accumulation}

There are three main sources of uncertainty in the reconstructed net accumulation in a given annual layer. Firstly, there is uncertainty in the precise location of seasonal anion concentration peaks. This is the result of uncertainties in (i) the use of discrete samples to define the chemical stratigraphy of the core, (ii) the timing of the deposition of the annual $\mathrm{SO}_{4}{ }^{2-}$ concentration peak used to define annual layers and (iii) the displacement of the anion peak by melt (Gjessing and others, 1993; Moore and others, 2005). We estimate the uncertainty due to discrete sampling as the fraction of the annual layer represented by a single sample. For example, in core A there are 10.8 samples per year, which means that one sample represents $\sim 9 \%$ of a given annual layer (Table 1). As the seasonal peak in snowfall $\mathrm{SO}_{4}{ }^{2-}$ concentration spans a 3 month period (Toom-Sauntry and Barrie, 2002), we estimate the uncertainty in the deposition timing of the annual $\mathrm{SO}_{4}{ }^{2-}$ concentration peak as $\pm 25 \%$. We have no way of estimating the displacement of this peak by melt. These uncertainties were combined to give a root-mean-square (rms) uncertainty due to peak location $\left(\sigma\left[c_{l}\right]\right)$ of between \pm 26 and $\pm 29 \%$ depending on core (core A: 27\%, B: 26\%, C: 27\%, D: $29 \%$ and E: $26 \%$ ). The second main source of uncertainty in net accumulation is due to the transfer of mass between annual layers by meltwater percolation $\left(\sigma\left[c_{\mathrm{p}}\right]\right)$. We estimate this uncertainty as the mean decrease in net accumulation variability in each core record between periods of lower (1963-88) and higher (post-1989) meltwater percolation. (The calculation of $\sigma\left[c_{\mathrm{p}}\right]$ (core A: 23\%, B: 9\%, C: 0\%, D: 18\% and E: 4\%) is described in section 3.2 below.) Thirdly, there is uncertainty in annual net accumulation due to the conversion of annual layer thicknesses from $\mathrm{m}$ to $\mathrm{m}$ w.e. $\left(\sigma\left[c_{\mathrm{C}}\right]\right)$ using the density profiles and core geometries measured in the field. The core sections recovered have a mean length of $29.8 \pm 2 \mathrm{~cm}$ and a mean mass of $1187 \pm 50 \mathrm{~g}$. The uncertainties in these measurements were taken as a percentage of the mean length and mass of the ice-core sections $( \pm 5 \%$ and $\pm 4 \%$, respectively), giving a combined rms error $\sigma\left[c_{\mathrm{c}}\right]$ of $\pm 6 \%$. The total uncertainty in the mean annual net accumulation at a core site $(\sigma[c])$ was calculated as:

$$
\sigma[c]=c \sqrt{\left(\sigma\left[c_{\mathrm{l}}\right]\right)^{2}+\left(\sigma\left[c_{\mathrm{p}}\right]\right)^{2}+\left(\sigma\left[C_{\mathrm{c}}\right]\right)^{2}} .
$$

The resulting uncertainty varied between \pm 0.06 and \pm 0.08 mw.e. $\mathrm{a}^{-1}( \pm 28$ to $\pm 36 \%$ of the mean annual net accumulation) depending on the core site (Table 1).

This analysis of uncertainty excludes the uncertainty associated with the dating of the core. Dating errors can result in true annual layers being split or combined, which has consequences for the assessment of the accumulation they contain. This source of uncertainty is presumably lowest near those horizons that can be dated independently (the surface and the $1963{ }^{137} \mathrm{Cs}$ bomb layer) and potentially 


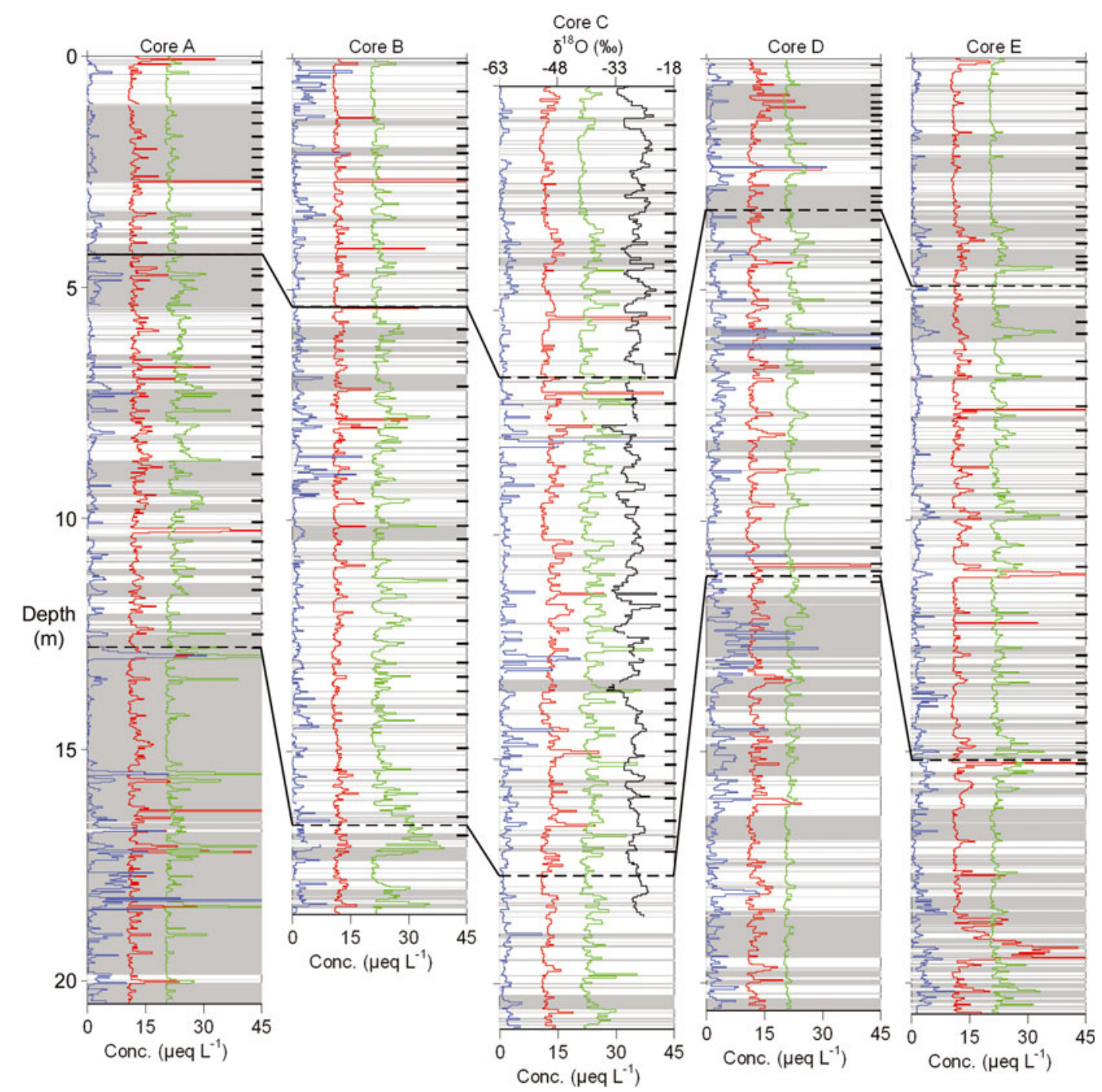

Fig. 3. $\mathrm{MSA}$ (blue), $\mathrm{Cl}^{-}$(red), $\mathrm{SO}_{4}{ }^{2-}$ (green) and $\delta^{18} \mathrm{O}$ (black) records with depth in the five shallow firn cores. To facilitate interpretation, $\mathrm{MSA}$ concentrations have been multiplied by 100 , and $\mathrm{Cl}^{-}$and $\mathrm{SO}_{4}{ }^{2-}$ concentrations have been translated from zero by 10 and $20 \mu \mathrm{EqL} \mathrm{L}^{-1}$, respectively. Grey shading indicates the portions of the cores composed of ice, both clear and bubbly, as opposed to firn (white shading). The $1963{ }^{137} \mathrm{Cs}$ 'bomb' horizon and the 1989 annual layer are connected between cores (dashed lines). The annual layers are identified in each core (dashes).

greatest near the middle of the reconstructed record. Because of this variability, we chose not to combine this dating-related uncertainty with the uncertainties included in Equation (1), and evaluated it separately. For all the cores, we estimated a dating uncertainty of \pm 1 year during the 1963-73 and 1993-2003 periods, and a dating uncertainty of \pm 2 years during the 1973-93 period. The associated maximum uncertainty in the accumulation associated with a single annual layer can thus be assumed to be one or two times the mean annual net accumulation rate for each core, but the actual error will be much less than this for most layers because the number of annual layers counted in each core is constrained to match the time interval between 1963 and the year of core recovery. To minimize the impact of this uncertainty on the analyses reported here, all time-series analyses were performed on 3 year running means of the reconstructed annual net accumulation records.

\subsection{Potential moisture-source areas}

To investigate the causes of variability in annual net accumulation on the ice cap, we attempted to evaluate temporal changes in the potential supply of moisture to the ice cap that resulted from variations in the pattern of atmospheric transport to the ice cap and the extent and distribution of areas of open water along the transport pathways. Potential moisture-source areas, defined as regions with open water that have a relatively high probability of being traversed by low-elevation $(<500 \mathrm{~m})$ air masses en route to Devon Ice Cap, were reconstructed for the 19792003 period. We focused on low-elevation air masses because previous work indicates that air masses travelling close to open-water surfaces are more likely to acquire moisture by evaporation than higher-elevation air masses (Reijmer and others, 2002).

Daily 120 hour kinematic back-trajectories for the period 1979-2003 were calculated for the summit of Devon Ice Cap $\left(75^{\circ} \mathrm{N}, 82^{\circ} \mathrm{W}\right)$ using the METEX model (Zeng and others, 2003) and US National Centers for Environmental Prediction/US National Center for Atmospheric Research (NCEP/NCAR) re-analysis data (Kalnay and others, 1996). Each trajectory describes the most probable upwind path taken by a parcel of air arriving $500 \mathrm{~m}$ above ground level at 
the summit of Devon Ice Cap at $0000 \mathrm{~h}$ local time each day. Similarly, Kahl and others (1997) compiled a 44 year daily back-trajectory record for the summit of the Greenland ice sheet using the once-daily $(0000 \mathrm{~h}) 400 \mathrm{~m}$ arrival. The choice of a once-daily sampling interval is justified on the grounds that we are interested in reconstructing synopticscale (day to week) and seasonal variations in regional airmass transport pathways (Kahl and others, 1997; Reijmer and others, 2002).

To identify those regions of the Arctic crossed by lowelevation air masses en route to Devon Ice Cap, all hourly back-trajectory points below $500 \mathrm{~m}$ in a given month were gridded on an 814-cell conic grid centred on the North Pole (hereafter G814). For a given G814 cell (indicated by subscript $\mathrm{x}$ ), the monthly site-specific low-elevation atmospheric transport density $\left(D_{\mathrm{mx}}\right)$ was computed according to:

$$
D_{\mathrm{mx}}=\frac{b_{\mathrm{mx}}}{A_{\mathrm{x}} \times d_{\mathrm{m}} \times 24 \text { hours d }^{-1}},
$$

where $b_{\mathrm{mx}}$ is the number of hourly back-trajectory points below 500 m elevation counted in a given G814 cell (hours), $A_{\mathrm{x}}$ is the area of the given G814 cell and $d_{\mathrm{m}}$ is the number of days in the given month.

Although site-specific low-elevation atmospheric transport provides a physical mechanism to link the ice cap with potential moisture-source regions, sea-ice cover is also an important control on the distribution of moisture sources (open water) in the polar regions. To improve the identification of potential moisture-source regions for Devon Ice Cap, we combined the monthly site-specific low-elevation atmospheric transport density history with a monthly open-water fraction $\left(O_{m y}\right)$ history. Monthly open-water fraction values were obtained from the US National Snow and Ice Data Center (NSIDC) Northern Hemisphere monthly sea-ice fraction dataset, gridded in a 4640-cell standard $1^{\circ}$ latitude cylindrical projection grid (hereafter G4640), and derived from passive microwave remote sensing using the NASA Team algorithm (Walsh, 1978; http://arctic.atmos.uiuc.edu/ SEAICE). Monthly open-water fraction is given by:

$$
O_{\mathrm{my}}=1-S_{\mathrm{my}}
$$

where $S_{\mathrm{my}}$ is the monthly sea-ice fraction in a given G4640 cell (indicated by subscript y) in a given month (indicated by subscript $\mathrm{m}$ ).

Each G814 gridcell in the monthly site-specific lowelevation atmospheric transport dataset encompasses multiple G4640 cells in the monthly open-water fraction dataset. Each G4640 cell was therefore assigned the monthly low-elevation atmospheric transport history of the G814 cell within which its centre coordinates reside. Monthly moisture-source index values $\left(M_{\mathrm{my}}\right)$ were generated for each G4640 cell in a given month by combining monthly low-elevation atmospheric transport and open-water fraction histories according to:

$$
M_{\mathrm{my}}=D_{\mathrm{mx}} \times O_{\mathrm{my}} .
$$

To express the monthly moisture-source index value of each G4640 cell as a dimensionless relative probability, monthly moisture-source index values were divided by a theoretical monthly maximum moisture-source index value $\left(M_{\mathrm{m}}^{\prime}\right)$, which is the theoretical limit that would be reached if both monthly low-elevation atmospheric transport density and monthly open-water fraction reached maxima $\left(D_{\mathrm{m}}^{\prime}\right.$ and $\left.O_{\mathrm{m}}^{\prime}\right)$ within a single cell which served as the sole moisture source for Devon Ice Cap in a given month:

$$
M_{\mathrm{m}}^{\prime}=D_{\mathrm{m}}^{\prime} \times O_{\mathrm{m}}^{\prime}
$$

To achieve this theoretical maximum moisture-source index value, all daily back-trajectory points in a given month would have to lie below $500 \mathrm{~m}$ elevation and have access to perpetually open water within the single G814 cell at the summit of Devon Ice Cap in which all trajectories terminate. Equation (2) is used to find $D_{\mathrm{m}}^{\prime}$, with $b_{\mathrm{mx}}$ taken as the theoretical maximum number of daily low-elevation backtrajectory points that could occur in a given gridcell in a given month ( 120 hours $\left.\mathrm{d}^{-1} \times d_{\mathrm{m}}\right)$ and $A_{\mathrm{x}}$ as the area of the terminal gridcell $\left(77788 \mathrm{~km}^{2}\right)$. Equation (5) gives $M_{\mathrm{m}}^{\prime}$; assuming an open-water fraction of 1 it has a value of $6.42 \times 10^{-4} \mathrm{~km}^{-2}$.

The relative probability that a given G4640 cell acts a moisture source in a given month $\left(P_{\mathrm{my}}\right)$ is then:

$$
P_{\mathrm{my}}=\frac{M_{\mathrm{my}}}{M_{\mathrm{m}}^{\prime}} \text {. }
$$

If $P_{\mathrm{my}}=0.01$, then an air mass transits within $500 \mathrm{~m}$ of open water in G4640 cell y and goes on to travel to the summit of Devon Ice Cap approximately once every 100 hours in month $\mathrm{m}$. Although calculated $P_{\mathrm{my}}$ values ranged between zero and 0.1 , only G4640 cells where the $P_{\text {my }}$ value surpassed 0.001 for at least one month a year were chosen for further study. Cells where $P_{\mathrm{my}}$ values are perpetually below 0.001 are unlikely to be important moisture-source areas. Monthly values of site-specific low-elevation atmospheric transport density $\left(D_{\mathrm{mx}}\right)$, sea-ice fraction $\left(S_{\mathrm{my}}\right)$ and relative moisture-source probability $\left(P_{\mathrm{my}}\right)$ were averaged for three seasons: late summer/early fall (July, August, September, October (JASO)); late spring/early summer (March, April, May, June (MAMJ)) and winter (November, December, January, February (NDJF)) (see Figs 4-6). Seasonal values were weighted according to the differing number of days in each month, and denoted as $D_{\text {sx }}, S_{\text {sy }}$ and $P_{\text {sy. }}$. These seasonal divisions were chosen because approximately twice as much accumulation occurs on Devon Ice Cap in JASO as in MAMJ, and little accumulation occurs during NDJF (Koerner, 2002). The NDJF season comprises January and February of a given year, and November and December of the previous year.

This simple calculation of $P_{\text {my }}$ values provides only a first approximation of the likely location of moisture sources, since important parameters that influence evaporative moisture uptake, such as air-mass temperature, relative humidity and wind speed, are ignored. Warmer air masses can hold more moisture than colder air masses (Serreze and Barry, 1999). Moisture-source probabilities may therefore be underestimated (overestimated) during the JASO (NDJF) season, as the air masses in all seasons are treated as equal when, in reality, a given JASO air mass probably takes up and transports more moisture than a given NDJF air mass. Similarly, the amount of moisture an air mass can take up decreases as the relative humidity of an air mass increases (Serreze and Barry, 2005). Therefore, relative moisturesource probabilities may be slightly enhanced (depressed) in the more continental (maritime) regions of the Arctic, such as the Queen Elizabeth Islands, Baffin Bay, where relative humidity is probably low (high). Finally, evaporation is also enhanced by higher wind speeds. Although moisture is transferred from open water to the shallow surface boundary layer primarily through diffusion, turbulent eddies are the 

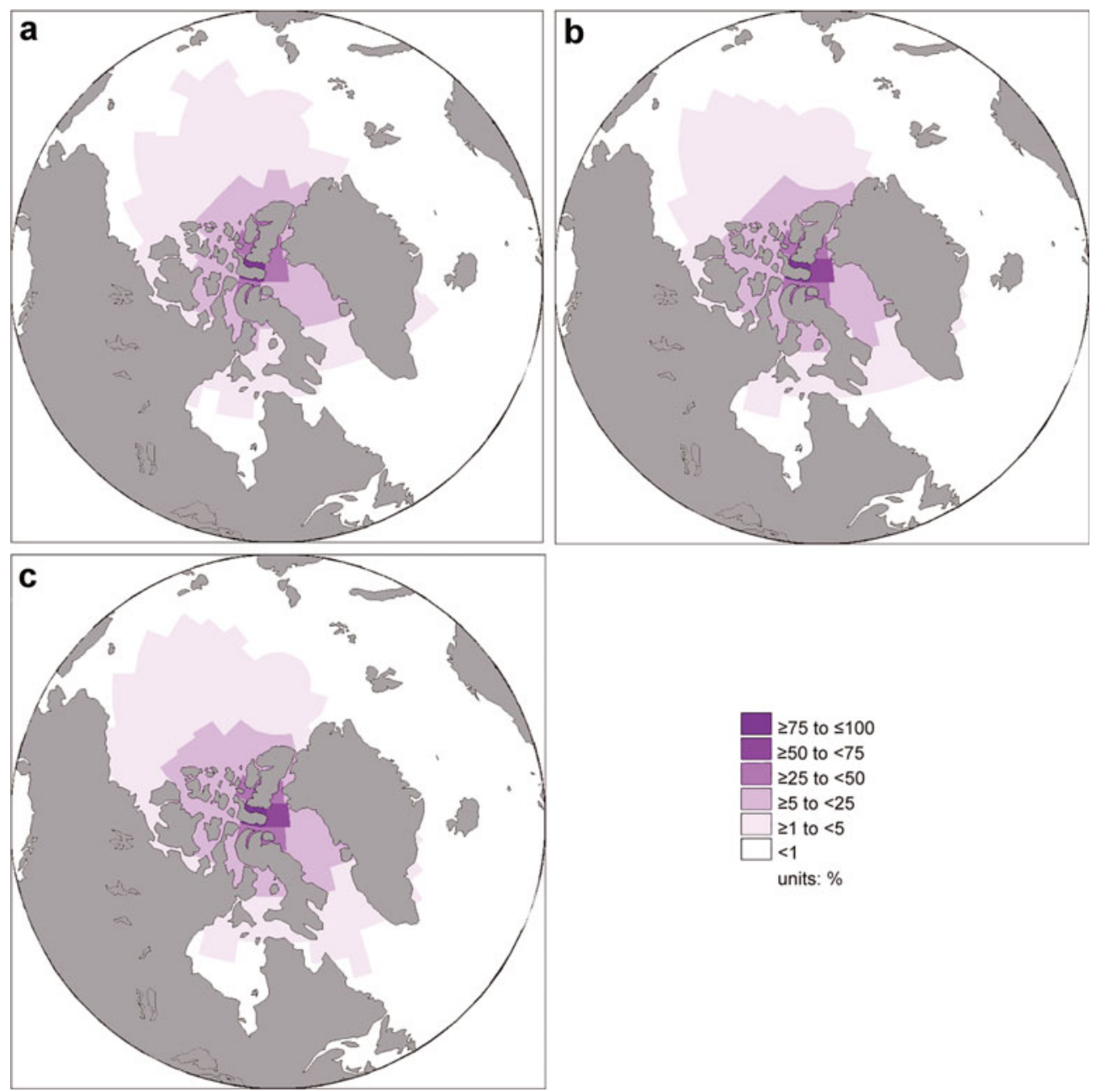

Fig. 4. The seasonal site-specific low-elevation atmospheric transport density $\left(D_{\mathrm{sx}}\right)$, during the period 1979-2003, in (a) the winter (NDJF), (b) late-spring/early-summer (MAMJ) and (c) late-summer/early-fall (JASO) seasons. $D_{\text {sx }}$ values for each G814 cell are expressed as a percentage of the maximum $D_{\text {sx }}$ value achieved in each season.

main method by which moisture is transferred to the rest of the troposphere (Serreze and Barry, 2005). Therefore, regions with relatively high mean wind speeds may have higher moisture-source probabilities than reported here, due to the effective transfer of moisture from the boundary layer to the rest of the troposphere.

\subsection{Annual net accumulation variability}

The influence of seasonal moisture-source probability variability on net accumulation was examined for the moisturesource region of interest (defined by $P_{\mathrm{my}}>0.001$ ) during the 1979-2003 period. Within this region, the mean relative moisture-source probabilities of the 4 year periods of highest (1984-87) and lowest (1994-97) annual net accumulation during the 1979-2003 period were compared. One-tailed $t$ tests, assuming equal variance, were performed for each gridcell to ensure that only cells exhibiting significant differences in JASO moisture-source probabilities between the high and low net accumulation 4 year periods were mapped. To examine the relative role of atmospheric and oceanic influences on relative moisture-source probability differences, significant differences in the sea-ice fraction and site-specific low-elevation air-mass transport density between the high and low net accumulation periods were also mapped.

\section{RESULTS}

\subsection{Reconstructed annual net accumulation}

Similar standard deviations of the annual net accumulation records indicate that the five cores exhibit similar amounts of interannual variability (Table 1). The stacked mean of the five reconstructed annual net accumulation records shows distinct periods of above (1964-67, 1971-79 and 1984-88) and below (1968-70, 1981-83 and 1989-2003) average annual net accumulation (Fig. 7). A two-tailed $t$ test, assuming equal variance, reveals that the mean annual net accumulation during the 1989-2003 period $(0.18 \pm$ $0.05 \mathrm{~m}$ w.e.) was significantly lower $(p<0.05)$ than in the 1963-88 period $(0.24 \pm 0.07 \mathrm{~m}$ w.e.).

As the reconstructed annual net accumulation records exhibit clear periods with above and below average annual net accumulation, they can be characterized as datasets dominated by red-noise processes as opposed to white-noise processes. This distinction is important when examining the significance of relationships between these core records. As the autocorrelation within these records is most likely to be physically based (i.e. meteorological explanations for the autocorrelation probably exist), white-noise statistics, which assume no autocorrelation, are not suitable for analyzing these relationships. Fleming and Clarke (2002) argued that 

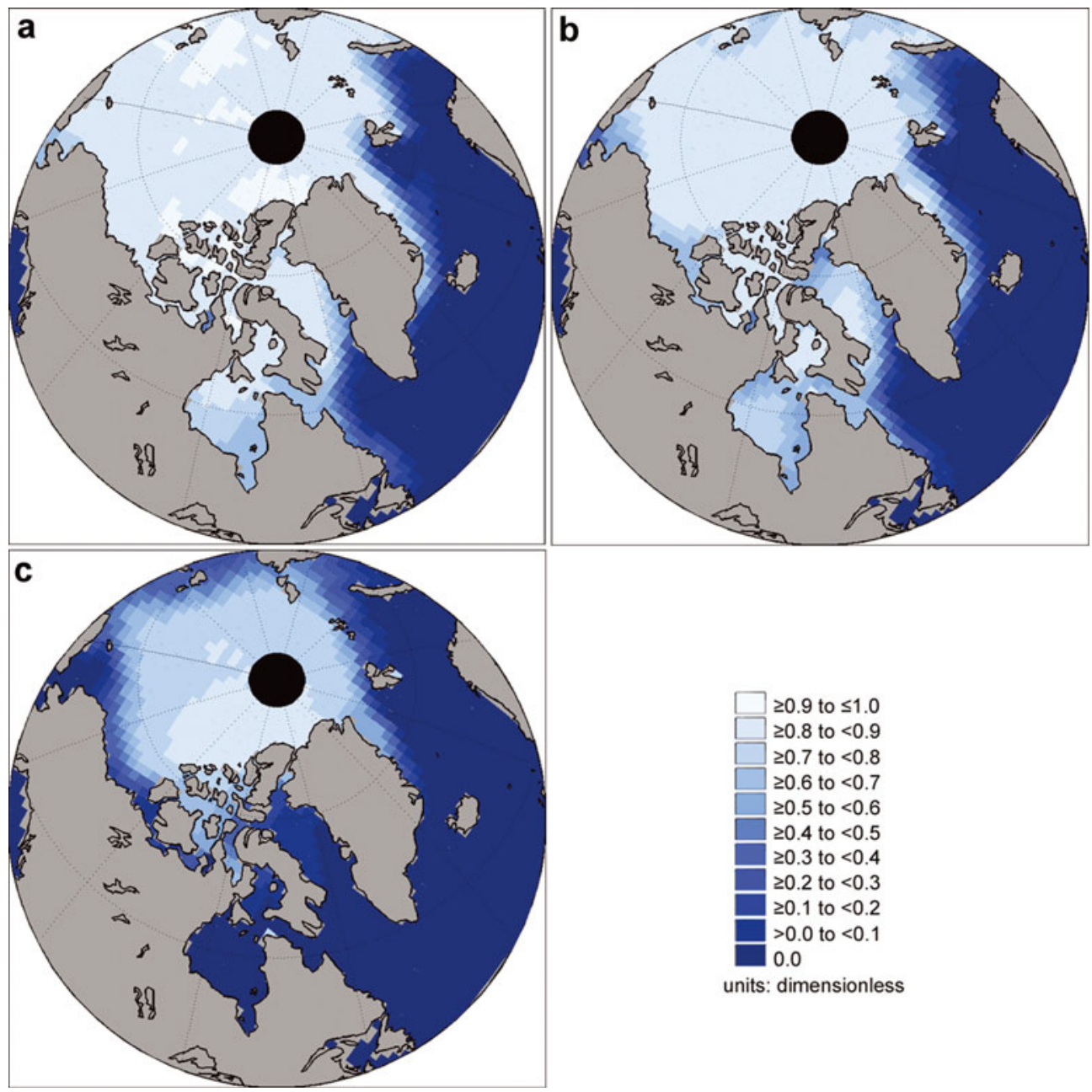

units: dimensionless

Fig. 5. The sea-ice fraction $\left(S_{\text {sy }}\right)$, during the period 1979-2003, in (a) the winter (NDJF), (b) late-spring/early-summer (MAMJ) and (c) latesummer/early-fall (JASO) seasons (http://arctic.atmos.uiuc.edu/SEAICE). $S_{\text {sy }}$ values for each G4640 cell are expressed as a fraction between 0 and 1.

the use of white-noise approaches to examine relationships between datasets with physically based autocorrelation 'can substantially and inappropriately reduce the power of trend significance tests'. To address this problem, they argued that non-parametric statistical approaches, such as Spearman's rank correlation, should be used to overcome the difficulties of autocorrelation in red-noise datasets, and evaluate the significance of relationships between time series (Fleming and Clarke, 2002).

The coherence of the net accumulation signal contained within the five ice cores was assessed through the crosscorrelation of the five individual reconstructed 3 year running mean net accumulation records and the 3 year running mean stacked net accumulation record, using Spearman's rank correlation. Although the use of a 3 year running mean compensates for dating uncertainty, it introduces nonphysically based autocorrelation into the datasets. A running mean reduces the effective sample size of a dataset by $1.5 / w$, where $w$ is the number of points used in the running mean (Moore and others, 2006). Therefore, a 3 year running mean results in an effective sample size of half the original sample size, which means correlations between 40 year datasets, for example, should be assessed using 19 degrees of freedom (Moore and others, 2006).

All five individual core records were found to be positively correlated $(p<0.01, r>0.52$ for $\mathrm{df}=19)$ to the
3 year stacked mean net accumulation record (Table 2). Therefore, we find the 3 year stacked mean net accumulation record to be representative of the individual core records which comprise it. The Spearman's rank correlation coefficient between individual core records is negatively correlated with the distance between core sites $(p<0.05$, $r=0.60$ for $\mathrm{df}=9$ ), which suggests that some spatial variability exists in the history of net accumulation on Devon Ice Cap and supports the stacking of the shallow firncore records to produce a composite history (Table 2; Fig. 1).

Good correlation between the annually measured massbalance record and the reconstructed net accumulation record is of paramount importance to instil faith in the use of shallow firn cores to reconstruct the net accumulation history. The measured mass-balance record used here is the mean of the annual mass-balance measurements at 1250 , 1350, 1450, 1550, 1650 and $1750 \mathrm{~m}$ elevations (the range covered by the firn cores) in the northwest sector of Devon Ice Cap (personal communication from R. Koerner, 2005; Fig. 7). Previous work has found that the mass balance of the northwest sector is a good proxy for the mass balance of the entire ice cap (Koerner, 1970). The significance of the relationship between 3 year running means of the reconstructed net accumulation record and the measured massbalance record was also examined using Spearman's rank correlation. Although there was a positive correlation 


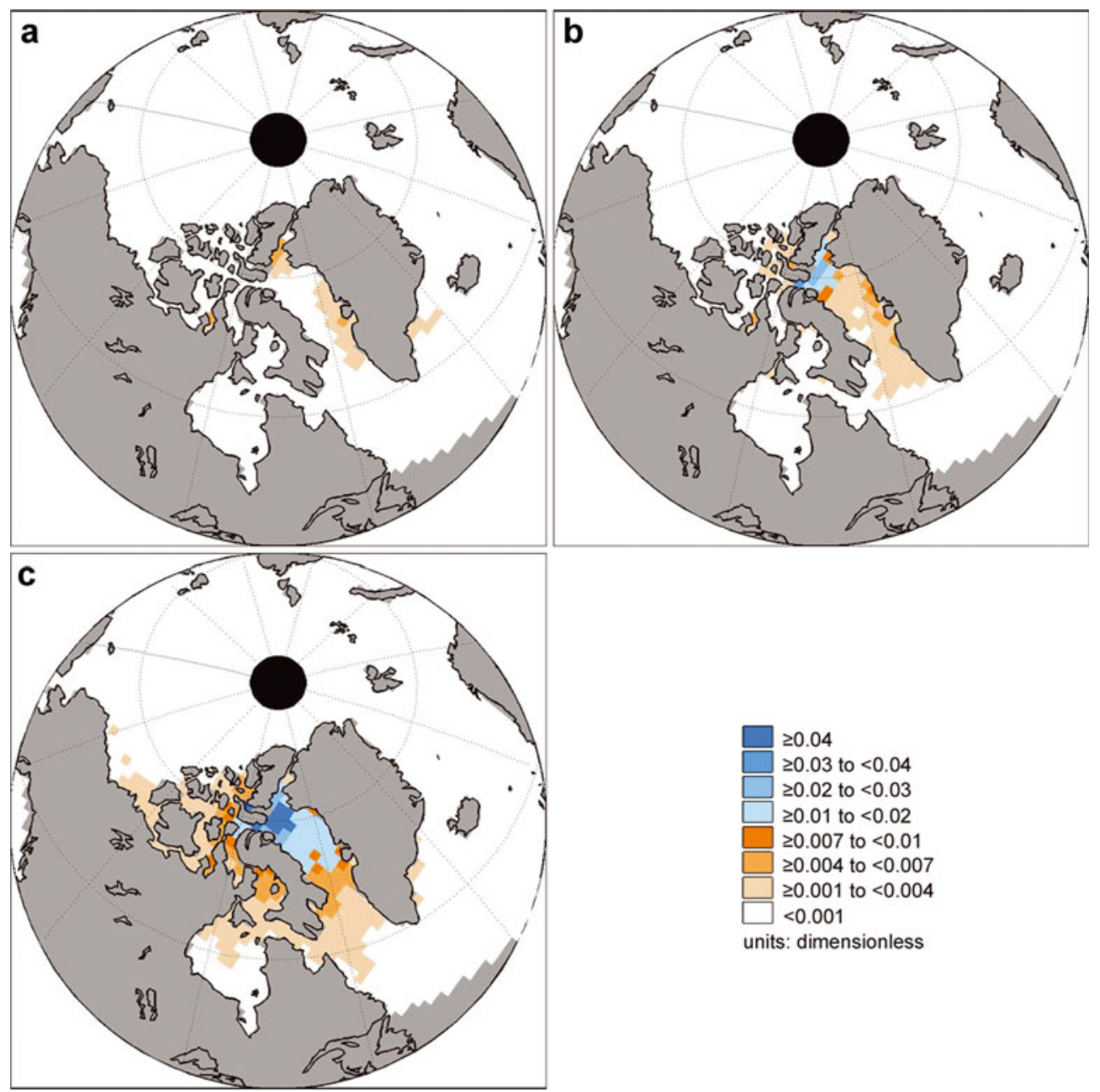

Fig. 6. Relative moisture-source probabilities $\left(P_{\mathrm{sy}}\right)$ in (a) the winter (NDJF), (b) late-spring/early-summer (MAMJ) and (c) late-ummer/early-fall (JASO) seasons, during the 1979-2003 period. $P_{\text {sy }}$ values for each G4640 cell are expressed as a dimensionless probability.

$(p<0.05, r=0.39$ for $\mathrm{df}=19)$ between the records during the whole 1963-2003 period, it was stronger $(p<0.05$, $r=0.62$ for $\mathrm{df}=12$ ) during the period of higher net accumulation (1963-88). There is no correlation $(p>0.05$, $r=-0.24$ for $\mathrm{df}=6$ ) during the post-1989 period of significantly lower net accumulation (Fig. 7), when the stacked mean net accumulation record consistently underestimates the measured mass balance (Fig. 7). As these two records pertain to different portions of the high-elevation region of Devon Ice Cap, the differences between them are likely to be real and indicative of spatial differences in net accumulation rates (Fig. 1).

\subsection{High-elevation melt}

The unfortunate result of meltwater percolation is that 'any one annual layer contains accumulation from more than one year, and yet does not contain all the accumulation from the year when the layer was deposited' (Koerner, 1970). This problem is probably most severe for those cores which experience the most melt and, within a single core, for periods of more intense melt. It is likely to influence both the reliability of the reconstructed net accumulation records and the comparison between the ice-core records and the measured mass balance of the ice cap. To characterize the spatial variation in the melt regime of the region of the ice cap from which the cores were collected, the mean number of melt days experienced at each core site between 2000 and 2004 was estimated using the regression model developed from QuikSCAT scatterometer data by Wang and others (2005). This model, which incorporates the influences of both site elevation and the distance of each core site from a fixed point in Baffin Bay, predicts annual melt durations of 18-31 days depending on core site (Table 1). The mean annual ice fraction in each ice core provides an independent measure of the melt intensity at each core site. During the 1963-2003 period, this fraction

Table 2. Spearman's rank correlation coefficients between the five individual 3 year mean net accumulation records and their stacked 3 year mean over the 1963-2003 period. The distances between core sites (in $\mathrm{km}$ ) are shown in parentheses

\begin{tabular}{lccccc}
\hline & Core A & \multicolumn{1}{c}{ Core B } & Core C & Core D & Core E \\
\hline Core B & $0.45^{*}(10)$ & - & - & - & - \\
Core C & $0.47^{*}(29)$ & $0.68^{\dagger}(19)$ & - & - & - \\
Core D & $-0.11(48)$ & $0.42^{*}(39)$ & $0.33(21)$ & - & - \\
Core E & $0.25(35)$ & $0.33(26)$ & $0.28(14)$ & $0.27(27)$ & - \\
Mean & $0.66^{\dagger}$ & $0.82^{\dagger}$ & $0.78^{\dagger}$ & $0.49^{\dagger}$ & $0.62^{\dagger}$ \\
\hline
\end{tabular}

Note: ${ }^{*}$ indicates $p<0.05$ and $^{\dagger}$ indicates $p<0.01$ for $\mathrm{df}=19$. 


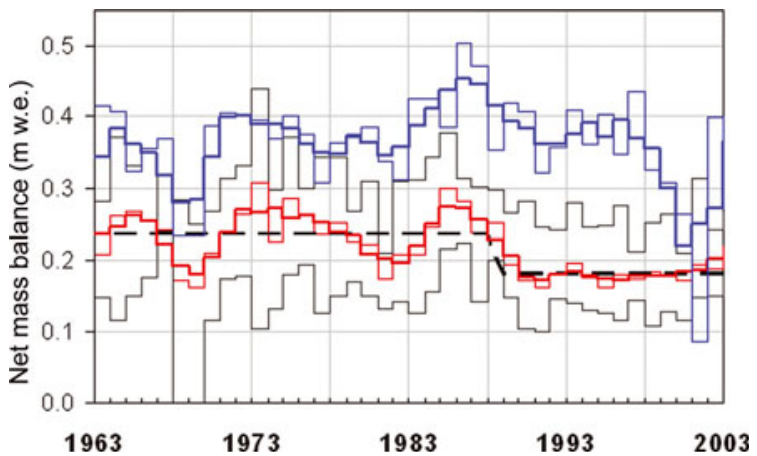

Fig. 7. The 3 year mean measured surface mass balance (blue) and 3 year stacked mean reconstructed net accumulation (red) are shown during the 1963-2003 period, as well as their respective annual records (thin black). The annual maximum and minimum reconstructed net accumulation values are indicated with thin grey lines. A significant decrease $(p<0.05 ; t$ test) in the mean annual net accumulation after 1988 is shown (dashed line).

varied between 0.16 and 0.62 , depending on the core site (Table 1) and was well correlated to the calculated number of melt days at each core site $(p<0.01, r=0.95$ for $\mathrm{df}=4)$.

Reliable ice-core chemistry records have been recovered from ice cores with annual ice fractions of close to 0.8 (Moore and others, 2005). The mean annual ice fraction in the five cores increased between the 1963-88 period $(0.33 \pm 0.24)$ and the post-1989 $(0.51 \pm 0.30)$ period (Table 3; Fig. 8). Significantly greater $(p<0.05$; two-tailed $t$ test assuming equal variance) $\delta^{18} \mathrm{O}$ values in core $\mathrm{C}$ during the 1989-2003 period $(-27.5 \pm 2.2 \%$ ), in comparison to the 1963-88 period $(-28.8 \pm 2.1 \%$ ), indicate warmer atmospheric temperatures in the later period that could account for the increase in annual ice fraction. However, the mean annual net accumulation rate also decreased between the 1963-88 period $\left(0.24 \pm 0.07\right.$ m w.e. $\left.\mathrm{a}^{-1}\right)$ and the post-1989 $\left(0.18 \pm 0.05 \mathrm{~m}\right.$ w.e. $\left.\mathrm{a}^{-1}\right)$ period, and this would also affect the annual ice fraction. The mean annual ice fraction of the earlier period corresponds to a mean annual ice thickness of $\sim 0.08 \mathrm{~m}$ w.e. $(0.33 \times 0.24 \mathrm{~m}$ w.e. $)$, while the mean annual ice thickness during the more recent period was $\sim 0.09 \mathrm{~m}$ w.e. $(0.51 \times 0.18 \mathrm{~m}$ w.e. $)$. Therefore, the amount of ice contained within the annual layers did increase (by $\sim 11 \%$ ) between the two periods, confirming that melt was probably more intense during the post-1989 period.

A homogenization of the anion chemistry, as evidenced by a decrease in the variability (standard deviation) of anion concentration measurements between the 1963-88 period and the 1989-2003 period, also suggests increased meltwater percolation during the recent period (Fig. 3; Moore and others, 2005). The mean variability in the five records decreased by $18 \%$ for MSA (from \pm 0.020 to $\pm 0.016 \mu \mathrm{Eq} \mathrm{L}^{-1}$ ), $6 \%$ for $\mathrm{Cl}^{-}$(from \pm 1.89 to $\pm 1.78 \mu \mathrm{Eq} \mathrm{L}^{-1}$ ) and $38 \%$ for $\mathrm{SO}_{4}{ }^{2-}$ (from \pm 2.45 to $\pm 1.54 \mu \mathrm{Eq} \mathrm{L}^{-1}$ ) between these two periods (Table 3). Although meltwater percolation has apparently increased over time, with annual percolation probably reaching greater depths in the recent period, it has failed to fully homogenize the annual layers (Fig. 3).

Although all five cores demonstrated an increase in annual ice fraction between the 1963-88 and 1989-2003 periods, the increase was only significant $(p<0.05)$ in cores $\mathrm{C}, \mathrm{D}$ and $\mathrm{E}$, according to two-tailed $t$ tests assuming

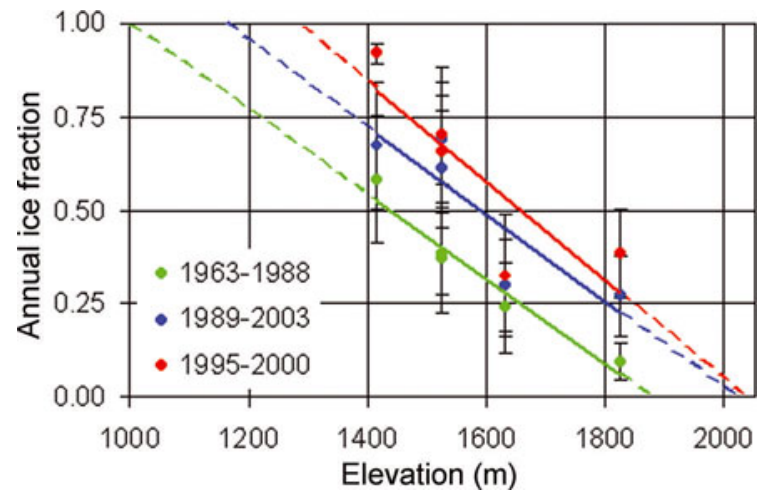

Fig. 8. The annual ice fraction-elevation relationships for the five shallow firn cores during the 1963-88, 1989-2003 and 1995-2000 periods. Vertical bars represent a half standard deviation in the annual ice fraction. The lower elevation limit of the dry snow zone (ice fraction $=0$ ) and upper elevation limit of the superimposed ice zone (ice fraction $=1$ ) can be approximated through extrapolation of regressions.

two samples with equal variance. Extrapolation of annual ice fraction-elevation relationships for the five core sites suggests that the upper limit of the superimposed ice zone (the lower limit of the wet snow zone), defined by a mean annual ice fraction of 1 , was found at $\sim 1000$ m elevation during the 1963-88 period and $1160 \mathrm{~m}$ during the 19892003 period (Fig. 8). Likewise, the upper limit of the percolation zone (the lower limit of the dry snow zone), defined by a mean annual ice fraction of 0 , was found at $\sim 1880 \mathrm{~m}$ elevation during the 1963-88 period and $2025 \mathrm{~m}$ during the 1989-2003 period, well above the $1930 \mathrm{~m}$ summit of Devon Ice Cap (Fig. 8).

The reconstructed net accumulation record exhibits decreased variability during the post-1989 period of poorer correlation with the measured record, in comparison to the 1963-88 period of better correlation (Fig. 7). This decrease in variability can be quantified by examining the change in the standard deviation of the net accumulation record of each core. The change ranged from $0 \mathrm{~m}$ w.e. in core $\mathrm{C}$ (the highest-elevation core) to $-0.05 \mathrm{~m}$ w.e. ( $23 \%$ of the mean annual net accumulation) in core $A$ (the lowest-elevation core; Table 3). If we assume no change in the interannual variability of snowfall between the two periods, this change in standard deviation provides a measure of the change in the redistribution of mass between annual layers by percolating meltwater between the two periods. The change in the standard deviation of net accumulation was calculated as a percentage of the 1963-2003 mean net accumulation rate for each core, and used as an estimate of the uncertainty in net accumulation due to mass transfer between annual layers by meltwater percolation $\left(\sigma\left[c_{\mathrm{p}}\right]\right)$ in section 2.3 above (A: $\pm 0.05 \mathrm{~m}$ w.e. $(23 \%)$; B: $\pm 0.02 \mathrm{~m}$ w.e. $(9 \%) ; \quad$ C: $\pm 0.00 \mathrm{~m}$ w.e. $(0 \%) ; \mathrm{D}: \pm 0.03 \mathrm{mw} . \mathrm{e} . \quad(18 \%)$; and $\mathrm{E}: \pm 0.01 \mathrm{~m}$ w.e. $(4 \%)$ (Table 3$)$ ).

\subsection{Site-specific low-elevation atmospheric transport density}

Variations in atmospheric transport pathways to the ice cap can result in variations in both firn chemistry and accumulation. Maps of seasonal (JASO, MAMJ and NDJF) site-specific low-elevation atmospheric transport densities provide a clear picture of the relative frequency with which 
Table 3. Comparisons between 1963-88 (in parentheses) and 1989-2003: mean annual net accumulation ( $c$; \pm std dev.), mean annual ice fraction $\left( \pm\right.$ std dev.) and the mean $\mathrm{MSA}, \mathrm{Cl}^{-}$and $\mathrm{SO}_{4}{ }^{2-}$ concentrations of all samples $( \pm$ std dev.) during both periods

\begin{tabular}{|c|c|c|c|c|c|c|}
\hline & Core A & Core B & Core C & Core D & Core $\mathrm{E}$ & Mean \\
\hline$c\left(m\right.$ w.e. $\left.a^{1}\right)$ & $\begin{array}{c}0.19 \pm 0.05 \\
(0.24 \pm 0.10)\end{array}$ & $\begin{array}{c}0.17 \pm 0.04 \\
(0.25 \pm 0.06)\end{array}$ & $\begin{array}{c}0.21 \pm 0.05 \\
(0.26 \pm 0.05)\end{array}$ & $\begin{array}{c}0.14 \pm 0.03 \\
(0.19 \pm 0.06)\end{array}$ & $\begin{array}{c}0.20 \pm 0.06 \\
(0.25 \pm 0.07)\end{array}$ & $\begin{array}{c}0.18 \pm 0.05 \\
(0.24 \pm 0.07)\end{array}$ \\
\hline Ice fraction & $\begin{array}{c}0.67 \pm 0.34 \\
(0.58 \pm 0.34)\end{array}$ & $\begin{array}{c}0.30 \pm 0.25 \\
(0.24 \pm 0.24)\end{array}$ & $\begin{array}{c}0.27 \pm 0.21 \\
(0.09 \pm 0.10)\end{array}$ & $\begin{array}{c}0.69 \pm 0.39 \\
(0.37 \pm 0.29)\end{array}$ & $\begin{array}{c}0.61 \pm 0.31 \\
(0.38 \pm 0.22)\end{array}$ & $\begin{array}{c}0.51 \pm 0.30 \\
(0.33 \pm 0.24)\end{array}$ \\
\hline$[\mathrm{MSA}]\left(\mu \mathrm{EqL}^{-1}\right)$ & $\begin{aligned} 0.005 & \pm 0.011 \\
(0.009 & \pm 0.019)\end{aligned}$ & $\begin{array}{c}0.014 \pm 0.025 \\
(0.011 \pm 0.019)\end{array}$ & $\begin{array}{c}0.009 \pm 0.015 \\
(0.013 \pm 0.022)\end{array}$ & $\begin{array}{c}0.011 \pm 0.019 \\
(0.022 \pm 0.021)\end{array}$ & $\begin{array}{c}0.005 \pm 0.011 \\
(0.010 \pm 0.018)\end{array}$ & $\begin{array}{c}0.009 \pm 0.016 \\
(0.013 \pm 0.020)\end{array}$ \\
\hline$\left[\mathrm{Cl}^{-}\right]\left(\mu \mathrm{Eq} \mathrm{L}{ }^{-1}\right)$ & $\begin{array}{c}2.26 \pm 1.59 \\
(3.01 \pm 1.73)\end{array}$ & $\begin{array}{c}1.81 \pm 1.40 \\
(1.79 \pm 1.42)\end{array}$ & $\begin{array}{c}2.47 \pm 1.38 \\
(3.65 \pm 2.30)\end{array}$ & $\begin{array}{c}3.25 \pm 2.96 \\
(2.58 \pm 1.94)\end{array}$ & $\begin{array}{c}1.81 \pm 1.59 \\
(2.23 \pm 2.07)\end{array}$ & $\begin{array}{c}2.32 \pm 1.78 \\
(2.65 \pm 1.89)\end{array}$ \\
\hline$\left[\mathrm{SO}_{4}{ }^{2-}\right]\left(\mu \mathrm{Eq} \mathrm{L}{ }^{-1}\right)$ & $\begin{array}{c}1.51 \pm 1.15 \\
(3.61 \pm 2.44)\end{array}$ & $\begin{array}{c}2.03 \pm 1.60 \\
(3.78 \pm 3.02)\end{array}$ & $\begin{array}{c}2.32 \pm 1.75 \\
(3.38 \pm 2.31)\end{array}$ & $\begin{array}{c}1.50 \pm 1.39 \\
(2.41 \pm 2.01)\end{array}$ & $\begin{array}{c}1.48 \pm 1.82 \\
(2.88 \pm 2.45)\end{array}$ & $\begin{array}{c}1.77 \pm 1.54 \\
(3.21 \pm 2.45)\end{array}$ \\
\hline
\end{tabular}

air masses arriving at the summit of Devon Ice Cap cross different regions of the Arctic at elevations below $500 \mathrm{~m}$ (Fig. 4). Site-specific low-elevation atmospheric transport density patterns are similar for all three seasons. Transport density is an inverse function of distance from the backtrajectory termination point, and values reach a maximum in all seasons where back-trajectories converge on the common G814 termination cell of Devon Ice Cap. Values of seasonal site-specific low-elevation atmospheric transport density range over three orders of magnitude across the Arctic. In all seasons, northern Baffin Bay and the Queen Elizabeth Islands (QEI) appear to be the primary regions crossed by low-elevation air masses en route to Devon Ice Cap, while southern Baffin Bay, the western Arctic Ocean and Foxe Basin/northern Hudson Bay are crossed less often. The Atlantic Ocean east of Greenland and the Eurasian portion of the Arctic Ocean are not traversed frequently in any season (Fig. 4). Either Greenland acts as an effective block to lowelevation air-mass transport from Europe and the east (Kahl and others, 1997), or the 120 hour back-trajectories are too short to capture transport paths from Eurasia.

\subsection{Regional sea-ice fraction}

During the NDJF season, high sea-ice fractions (low openwater fractions) occur throughout the Canadian Arctic Archipelago and Baffin Bay (Fig. 5). During the MAMJ season, as the polar pack margin migrates northward, the sea-ice fraction begins to decrease in both Hudson and Baffin Bays, along the Eurasian shelves and in the North Open Water (NOW) Polynya (Fig. 5). During the JASO season, Baffin Bay has a low sea-ice (high open-water) fraction, and sea-ice fractions also reach a minimum along the Eurasian shelves, in the coastal zone of the Beaufort Sea, throughout the QEI and in Hudson Bay (Fig. 5).

\subsection{Moisture-source probabilities}

The coupling of site-specific low-elevation atmospheric transport densities with the observed regional open-water fraction record allows investigation of temporal and spatial variations in the relative probability that a given G4640 cell acts as a moisture source for Devon Ice Cap in a given season. Primary moisture-source areas were defined as regions where $P_{\text {sy }} \geq 0.01$ (blue in Fig. 6), while secondary moisture-source areas were defined as regions where $0.001<P_{\text {sy }} \leq 0.01$ (orange in Fig. 6). During the NDJF season, no primary moisture-source areas are found within
5 days transit time of Devon Ice Cap, as relative moisturesource probabilities drop to near zero in most G4640 cells. Only localized bands of secondary moisture-source areas are inferred along the Greenland coast and in the NOW region (Fig. 6). During the MAMJ season, a primary moisture-source area is inferred in the NOW region, and the remainder of Baffin Bay is inferred to be a secondary moisture source (Fig. 6). During the JASO season, the main accumulation season on Devon Ice Cap (Koerner, 2002), the northern half of Baffin Bay is inferred to be a primary moisture-source area, while the southern half of Baffin Bay, the Labrador Sea, the QEI, the southeast Beaufort Sea and Foxe Basin/northern Hudson Bay are inferred to be secondary moisture-source regions (Fig. 6). Relative moisture-source probabilities surpass 0.04 in northern Baffin Bay in JASO, which represents one air mass passing within $500 \mathrm{~m}$ of open water en route to the summit of Devon Ice Cap every 25 hours, or almost daily, for the entire season in this region. These findings are consistent with the observation that most accumulation on Devon Ice Cap occurs during the JASO season, with the least accumulation during the NDJF season, and intermediate accumulation during the MAMJ season (Koerner, 2002).

A comparison of the JASO relative moisture-source probabilities during the 4 year periods of highest (1984-87) and lowest (1994-97) net accumulation shows significantly higher $(p<0.05 ; t$ test) relative moisture-source probabilities during the high net accumulation period in the region of the NOW Polynya (Fig. 9). The magnitude of this increase $\left(\Delta P_{\text {sy }}>0.01\right)$ is $\sim 25 \%$ of the mean $1979-2003$ JASO season $P_{\text {sy }}$ value in the NOW region $\left(P_{\text {sy }} \approx 0.04 ;\right.$ Fig. 6$)$. There is also a significant decrease $(p<0.05 ; t$ test $)$ in relative moisture-source probabilities in the Beaufort Sea and the QEI, and a significant increase $(p<0.05 ; t$ test $)$ in Ungava Bay during the high net accumulation period (Fig. 9).

The significant increase in relative moisture-source probabilities in the NOW region appears to be caused by both a significant decrease $(p<0.05 ; t$ test $)$ in sea-ice fraction and a significant increase $(p<0.05$; $t$ test) in sitespecific low-elevation atmospheric transport density (Fig. 9). Barber and others (2001) found that the deepening of a Greenland low-pressure trough, due to an east-west temperature gradient across the NOW region and Baffin Bay, enhances northerly winds across the NOW region, which results in a cyclonic gyre in northern Baffin Bay and the formation of an ice bridge across Nares Strait that leads to the opening of the NOW Polynya. This link between 


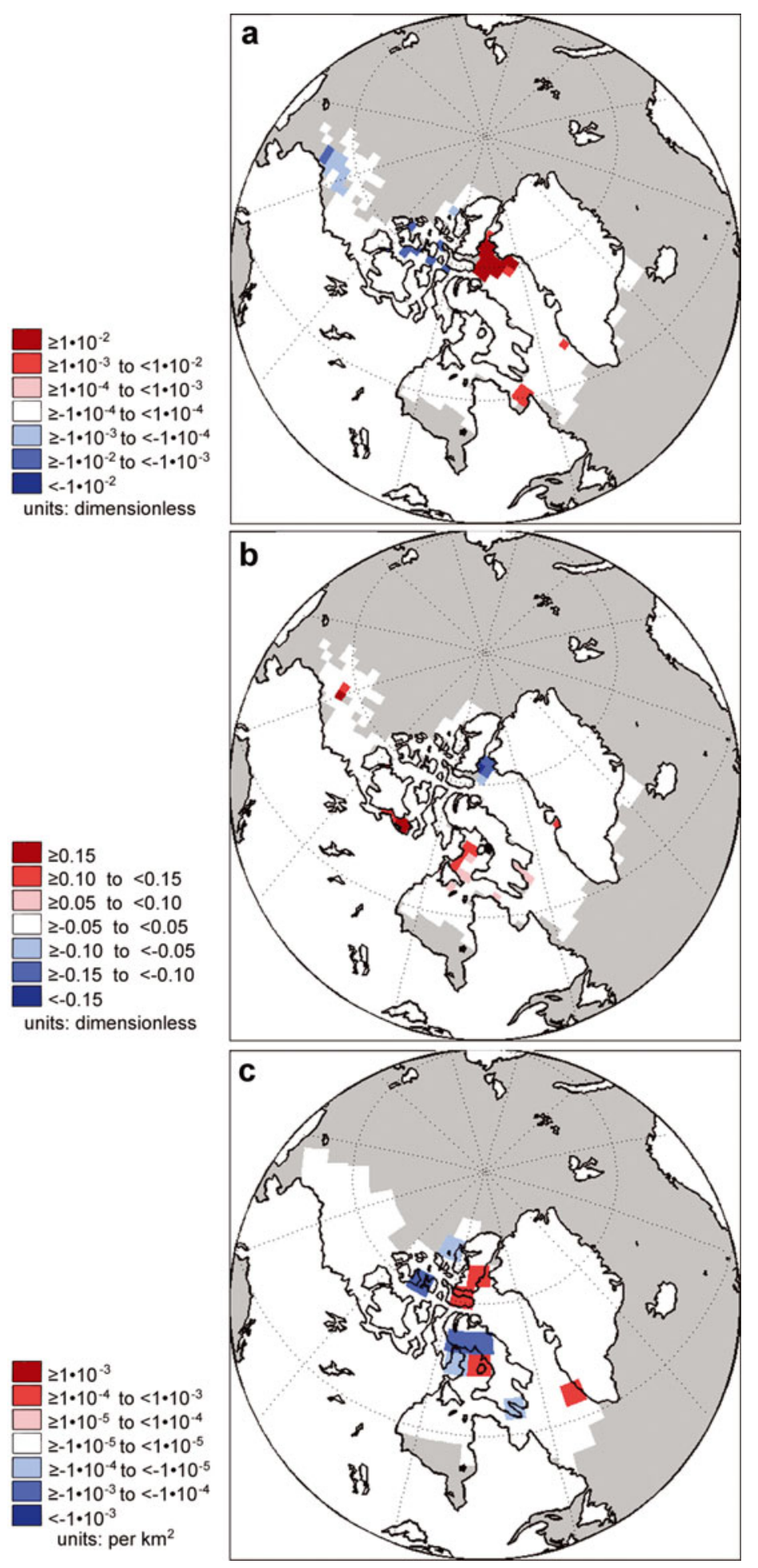

Fig. 9. Significant differences $\left(p<0.05 ; t\right.$ test) in JASO relative moisture-source probabilities $\left(P_{\text {sy }}\right)\left(\right.$ a), sea-ice fraction $\left(S_{\text {sy }}\right)(b)$ and sitespecific low-elevation atmospheric transport density $\left(D_{\mathrm{sx}} ; \mathrm{km}^{-2}\right)$ (c) between high (1984-87) and low net accumulation (1994-97) periods. Red indicates significantly higher values during the high net accumulation period. Grey areas indicate regions with $P_{\mathrm{my}}<0.001$ throughout the year.

atmospheric circulation and sea-ice motion, extent and concentration could therefore account for the history of moisture-source probabilities in the NOW region.

The significant decrease in relative moisture-source probabilities in the Beaufort Sea during the high net accumulation period may be due to a small area of significantly increased ( $p<0.05 ; t$ test) sea-ice fraction, as there is no significant change $(p>0.05 ; t$ test) in site-specific low-elevation atmospheric transport density in this region (Fig. 9). The significant decrease in relative moisture-source probabilities in the QEI during the high net accumulation period is probably due to a significant decrease $(p<0.05$; $t$ test) in site-specific low-elevation atmospheric transport density from this region, as there is no significant change ( $p>0.05 ; t$ test) in the sea-ice fraction within the QEI between the high and low net accumulation periods. 


\section{DISCUSSION: HIGH-ELEVATION THICKENING}

Airborne laser altimetry measurements, conducted in 1995 and 2000, suggested that the high-elevation region of Devon Ice Cap thickened at a rate of up to $20 \mathrm{~cm} \mathrm{a}^{-1}$, while the lowelevation region thinned at a rate of up to $40 \mathrm{~cm} \mathrm{a}^{-1}$ (Abdalati and others, 2004). Although Abdalati and others (2004) suggested that these observations can be explained by anomalously high accumulation throughout the Arctic during the observation period (1995-2000), compared to the 52 year mean from three weather stations in the Canadian Arctic (Iqaluit, Clyde River and Eureka), our reconstructed record clearly demonstrates anomalously low mean annual net accumulation during this period $\left(0.18 \pm 0.01 \mathrm{mw}^{\mathrm{e}} \mathrm{.} \mathrm{a}^{-1}\right)$ in comparison to the mean annual net accumulation for the entire 1963-2003 period $\left(0.22 \pm 0.04 \mathrm{mw}^{\mathrm{m}} \mathrm{e} \cdot \mathrm{a}^{-1}\right)$. This finding is supported by the measured mass-balance record from the high-elevation region $(1250-1750 \mathrm{~m})$ of the northwest sector of the ice cap (Fig. 7), as well as by the measured mean mass balance at all elevations $(0-1750 \mathrm{~m})$, which was anomalously low during the $1995-2000$ period $(-0.43 \pm 0.17 \mathrm{~m}$ w.e. $)$ in comparison to the 1961-2003 mean $(-0.31 \pm 0.17 \mathrm{~m}$ w.e.; cf. fig. 2 in Koerner, 2005). This decrease in annual net accumulation during the 1995-2000 period, relative to the $\sim 40$ year mean, would be expected to result in surface lowering or ice-cap thinning, rather than the thickening observed by altimetry.

Changes in the rate of firnification, which may be indicated by changes in the annual ice fraction, also influence the relative elevation of an ice-cap surface. The reconstructed annual ice fraction record of Devon Ice Cap suggests that the mean annual ice fraction of the five cores was higher during the post-1989 period $(0.51 \pm 0.30)$ than the during $1963-88$ period $(0.33 \pm 0.24)$. The mean annual ice fraction during the 1995-2000 laser altimetry survey period was even higher $(0.60 \pm 0.24$; Fig. 8). Trends of increasing annual ice fraction, over the last $70-130$ years, have been recognized on ice caps throughout the Arctic, and are interpreted as evidence of climate change (Dowdeswell, 1995). Given the firn-core evidence presented above for increased air temperatures, meltwater percolation and annual ice fractions after 1989, it seems certain that the rate of firnification was higher during the 1989-2003 period than during the 1963-1988 period. An increase in the rate of firnification would be expected to result in overall surface lowering, especially when accompanied by a decrease in net accumulation. Given this conclusion, a reduction in ice outflow from the high-elevation region of the ice cap may be a more plausible explanation of the thickening of the highelevation parts of the ice cap between 1995 and 2000 than a change in surface mass balance.

A fuller discussion of the apparent inconsistency between the laser altimetry observations and current surface massbalance trends will be presented elsewhere. One possible explanation of a reduction in outflow from the highelevation regions of the ice cap is that neoglacial cooling has only recently reached the bed of Devon Ice Cap and begun to stiffen the basal ice, resulting in reduced internal deformation and outflow velocities.

\section{CONCLUSIONS}

A reconstructed annual net accumulation record for the period 1963-2003 was derived from five shallow firn cores recovered from the high-elevation region of Devon Ice Cap. The stacked mean annual net accumulation was significantly lower during the 1989-2003 period than in the 196388 period. Conversely, the mean annual ice fraction in the five cores was higher (significantly higher in three cores) during the post-1989 period than in the 1963-88 period. There appears to be a good correlation between the reconstructed mean net accumulation record and the observed northwest sector high-elevation surface massbalance record.

Relative moisture-source probabilities reach a maximum in northern Baffin Bay in JASO, and a minimum throughout the Arctic in NDJF. A comparison of the JASO relative moisture-source probabilities during the 4 year periods of highest (1984-87) and lowest (1994-97) annual net accumulation shows significantly higher relative moisture-source probabilities during the high annual net accumulation period in the NOW Polynya region. These elevated moisture-source probabilities appear to be the result of both a significant increase in low-elevation atmospheric transport density and a significant decrease in sea-ice fraction.

The firn-core records indicate that the rate of annual net accumulation was lower, and the rate of firnification (indicated by the water equivalent ice thickness within annual layers) was higher than the 1963-2003 mean during the laser altimetry survey period (1995-2000). We therefore suggest that a change in ice dynamics, such as a decrease in ice outflow from the accumulation zone of the ice cap (possibly related to the penetration of the neoglacial cold wave to the bed of the ice cap), may be responsible for the observed high-elevation thickening of Devon Ice Cap during this period, rather than a change in surface mass balance.

\section{ACKNOWLEDGEMENTS}

We thank the Polar Continental Shelf Project (PCSP contribution No. 029-07), the Natural Sciences and Engineering Research Council of Canada, the ArcticNet Network of Centres of Excellence, the Canadian Foundation for Innovation, the Canadian Circumpolar Institute, the Northern Scientific Training Program, the Alberta Science and Research Investment Program and the Alberta Ingenuity Fund for financial and logistical support. We also thank the Nunavut Research Institute and the communities of Resolute Bay and Grise Fjord for permission to conduct fieldwork. H. Bigelow, L. Hyrciw, L. Nicholson, J. Barker and N. Atkinson provided assistance in the laboratory, and J. Davis, D. Burgess, F. Cawkwell, C. Bell and S. Williamson assisted with the fieldwork.

\section{REFERENCES}

Abdalati, W. and 9 others. 2004. Elevation changes of ice caps in the Canadian Arctic Archipelago. J. Geophys. Res., 109(F4), F04007. (10.1029/2003JF000045.)

Barber, D.G., J.M. Hanesiak, W. Chan and J. Piwowar. 2001. Seaice and meteorological conditions in northern Baffin Bay and the North Water polynya between 1979 and 1996. Atmos.Ocean, 39(3), 343-359.

Burgess, D.O. and M.J. Sharp. 2004. Recent changes in areal extent of Devon ice cap, Nunavut, Canada. Arct. Antarct. Alp. Res., 36(2), 261-271.

Cazenave, A. and R.S. Nerem. 2004. Present-day sea level change: observations and causes. Rev. Geophys., 42(3), RG3001. (10.1029/2003RG000139.) 
Dowdeswell, J.A. 1995. Glaciers in the High Arctic and recent environmental change. Philos. Trans. R. Soc. London, Ser. A, 352(1699), 321-334.

Dowdeswell, J.A., T.J. Benham, M.R. Gorman, D. Burgess and M. Sharp. 2004. Form and flow of Devon Island ice cap, Canadian Arctic. J. Geophys. Res., 109(F2), F02002. (10.1029/ 2003JF000095.)

Dunphy, P.P. and J.E. Dibb. 1994. ${ }^{137}$ Cs gamma-ray detection at Summit, Greenland. J. Glaciol., 40(134), 87-92.

Dyurgerov, M.B. and Meier, M.F. 2005. Glaciers and the changing Earth system: a 2004 snapshot. Boulder, CO, University of Colorado. Institute of Arctic and Alpine Research. (INSTAAR Occasional Paper 58).

Fleming, S.W. and G.K.C. Clarke. 2002. Autoregressive noise, deserialization, and trend detection and quantification in annual river discharge time series. Can. Water Res. J., 27(3), 335-354.

Gjessing, Y., I. Hanssen-Bauer, Y. Fujii, T. Kameda, K. Kamiyama and T. Kawamura. 1993. Chemical fractionation in sea ice and glacier ice. Bull. Glacier Res., 11, 1-8.

Kahl, J.D.W., D.A. Martinez, H. Kuhns, C.I. Davidson, J.L. Jaffrezo and J.M. Harris. 1997. Air mass trajectories to Summit, Greenland: a 44-year climatology and some episodic events. J. Geophys. Res., 102(C12), 26,861-26,875.

Kalnay, E. and 21 others. 1996. The NCEP/NCAR 40-year reanalysis project. Bull. Am. Meteorol. Soc., 77(3), 437-471.

Koerner, R.M. 1970. The mass balance of the Devon Island ice cap, Northwest Territories, Canada, 1961-66. J. Glaciol., 9(57), 325-336.

Koerner, R.M. 2002. Glaciers of the High Arctic islands. In Williams, R.S. and J.G. Ferrigno, eds. Satellite image atlas of glaciers of the world. US Geol. Surv. Prof. Pap. 1386-J, J111-J146.

Koerner, R.M. 2005. Mass balance of glaciers in the Queen Elizabeth Islands, Nunavut, Canada. Ann. Glaciol., 42, 417-423.
Moore, J.C., A. Grinsted, T. Kekonen and V. Pohjola. 2005. Separation of melting and environmental signals in an ice core with seasonal melt. Geophys. Res. Lett., 32(10), L10501. (10.1029/ 2005GL023039.)

Moore, J.C., T. Kekonen, A. Grinsted and E. Isaksson. 2006. Sulfate source inventories from a Svalbard ice-core record spanning the Industrial Revolution. J. Geophys. Res., 111(D15), D15307. (10.1029/2005JD006453.)

Pohjola, V.A. and 6 others. 2002. Reconstruction of three centuries of annual accumulation rates based on the record of stable isotopes of water from Lomonosovfonna, Svalbard. Ann. Glaciol., 35, 57-62.

Reijmer, C.H., M.R. van den Broeke and M.P. Scheele. 2002. Air parcel trajectories and snowfall related to five deep drilling locations on Antarctica based on the ERA-15 dataset. J. Climate, 15(14), 1957-1968.

Serreze, M. and R.G. Barry. 2005. The Arctic climate system. Cambridge, etc., Cambridge University Press. (Cambridge Atmospheric and Space Science Series.)

Toom-Sauntry, D. and L.A. Barrie. 2002. Chemical composition of snowfall in the high Arctic: 1990-1994. Atmos. Environ., 36(15-16), 2683-2693.

Walsh, J. E. 1978. A data set on Northern Hemisphere sea ice extent, 1953-76. Glaciol. Data, World Data Center A for Glaciol. <Snow and Ice>, Boulder, GD-2, part 2, 49-51.

Wang, L., M.J. Sharp, B. Rivard, S. Marshall and D. Burgess. 2005. Melt season duration on Canadian Arctic ice caps, 2000-2004. Geophys. Res. Lett., 32(19), L19502. (10.1029/2005GL023962.)

Zeng, J., M. Katsumoto, R. Ide, M. Inagaki, H. Mukai and Y. Fujinuma. 2003. Development of meteorological data explorer for Windows. In Fujinuma, Y., ed. Data analysis and graphic display system for atmospheric research using PC. Tsukuba, Ibaraki, National Institute for Enviornmental Studies. Center for Global Environmental Research, 19-73. (CGER-M012-2003.) 